\title{
OPTIMIZATION OF WELDING CYCLE TIME BY ESTABLISHING FULL GMAW PROCESS (STT AND P-GMAW) THROUGH A NEWLY DESIGNED SEMI-AUTOMATIC WELDING POSITIONER
}

\author{
R.Alagesan ${ }^{1}$, T.Senthil Kumar ${ }^{2}$ \\ ${ }^{1}$ M.E Thermal Engineering, University College of Engg, BIT campus, Tiruchirappalli-24, Tamil Nadu, India \\ ${ }^{2}$ Head, Department of Automobile Engg, University College of Engg, BIT campus, Tiruchirappalli -24, Tamil Nadu, \\ India
}

\begin{abstract}
Alloy steel materials are predominantly used in the manufacturing of headers in thermal power plant boilers. Generally the hand hole pipe and dish end component are provided in the header for the inspecting the inner surface of the header. Conventionally the welding of dish end with hand hole pipe of the header is carried out using manual GTAW welding process for root pass and manual SAW welding process for filler passes which is a time consuming process. Thus it is substituted with a semi-automatic welding process i.e., STT-root pass followed by the pulsed GMAW for filler passes through a newly designed welding positioner. This semi-automatic welding process optimizes the cycle time and increases the productivity rate. Also the new welding processSTT and P-GMAW is established by following optimization technique of Taguchi's orthogonal array method and ensuring the weld quality performance through X-Radiography, mechanical tests impact test and hardness test.
\end{abstract}

Keywords-Alloy steel Gr-22 material; STT welding process; GTAW; pulsed GMAW welding process ; hand hole; dish end; semi-automatic welding positioner; Taguchi's orthogonal array method ***

\section{INTRODUCTION}

In a thermal power plant the prime mover is steam driven. Water is heated, turns into steam and spins a steam turbine which drives an electrical generator. After it passes through the turbine, the steam is condensed in a condenser and recycled to where it was heated; this is known as a Rankine cycle. The important pressure parts of boiler include headers, re heaters, super heaters, water wall panels, burner panels. The headers are predominantly of the alloy steel Gr.22 material.The headers are provided with hand hole and dish end at one of its edge useful for maintenance of the headers .The hand hole pipe with dish end over header is shown in Figure. 1

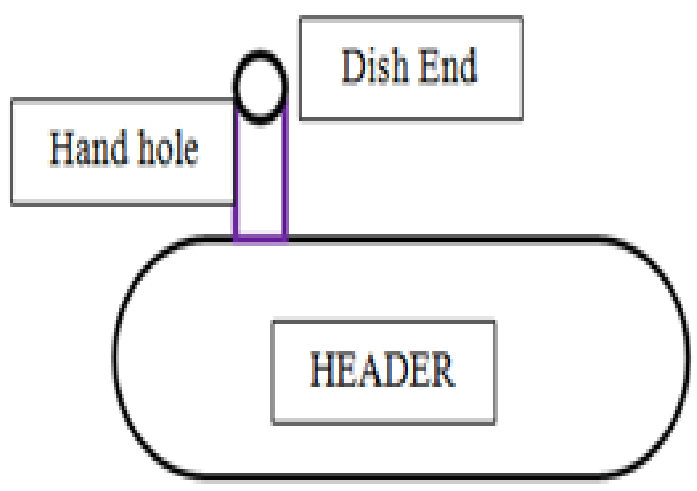

Fig. 1 Scheme showing hand hole with header

\section{PROBLEM DEFINITION AND SOLUTION}

Headers are used for the circulation of steam and water in the boiler and play a vital role in the fluid transfer required for the performance of the boiler through achieving high thermal heat output required for expansion in the turbine. Thus during maintenance of the header it is provided with a hand hole at each header end covered with dish end.Conventionally the welding of dish end to the hand hole is done using a manual GTAW process for root pass and manual SMAW welding process for filler pass which involves a huge time of about 8 hours for the completion of one number of hand hole to the dish end butt joint. Hence to reduce this cycle time an alternative process that shall be semi-automated is designed to optimize the cycle time and increasing the productivity. Accordingly a new welding positioner is designed as in the Figure. 2 and the welding processes suitable for semiautomatic operation are selected. Hence root pass welding using STT welding process and filler passes by Pulsed GMAW welding process is planned for the semi-automatic welding process. The STT welding process using low heat input is used for ensuring proper toughness, mechanical properties and metallurgical properties of the weldment root pass equivalent to GTAW process. Also the quality of welding will be good equivalent to the TIG root pass with reduced welding defects of lack of fusion, incomplete penetration problem. Also the STT root pass shall be followed by pulsed GMAW welding process suitable for semi-automatic welding process. 


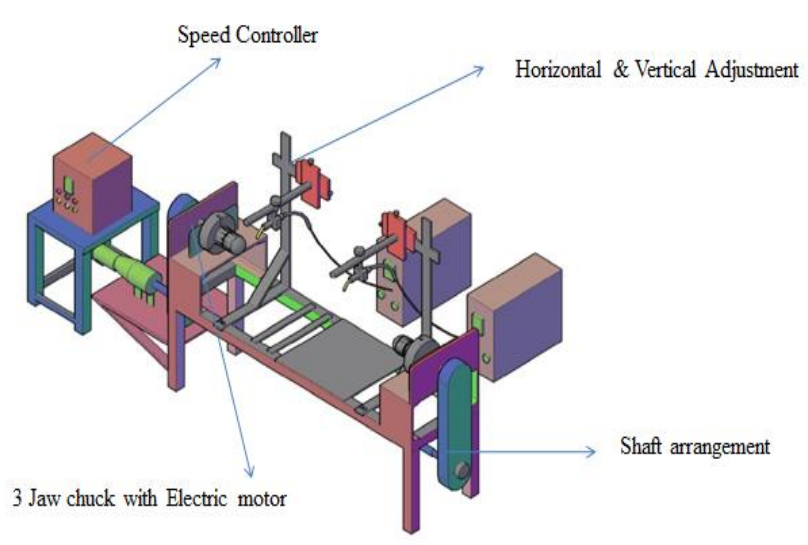

Fig. 2 Newly designed semi-automatic welding positioner

\subsection{STT Welding Process}

STT process (Surface Tension Transfer). is successfully used for performing of root passes at thick steam boilers pipes and chambers. The specific of STT welding process is application of impulse technique but with short arc metal transfer in electric arc. That is something new in relationship to other arc welding processes. The STT welding process is suitable for welding of thin plates, also. It has very low heat input what is interesting from residual stresses and deformations reduction point of view.

STT (Surface Tension Transfer) welding process is modern, high efficient and high quality welding process for thin wall materials joining and joining at root passes of thick materials. STT welding power source provide stabile main welding parameters during welding process which enable welding by "short circuit arc". The material transfer in electric arc is founded on surface tension force between weld pool and melted bead in electric arc. STT unit frequently and precisely controls welding current during welding. It sets an optimal welding parameters (which are stabile) by significant changing of arc length and "stick out". Principally, it is welding unit with possibility of welding parameters changing in milliseconds in order to obtain an optimal quality of welded joint. It is designed as a semiautomatic welding process for application where welding speed and "stick out" are variable. At STT welding process it is possible to use different shielding gases and gases mixtures (CO2, Ar$82 \%+\mathrm{CO} 2-18 \%$, Ar- $98 \%+\mathrm{CO} 2-2 \%, \ldots)$, depending on application in praxis. Welding processes suitable for individual pipes joining and pipes joining in pipes systems (membrane wall, membrane panel) are interesting in steam boiler production which is a specific type of production due to different material types, thickness, diameters, weld joint shapes, Conventional approach for pipes joining in steam boiler industry up to $\varnothing 88 \mathrm{~mm}$ is manual or automatic TIG welding process (Tungsten Inert Gas) as a single bead or multi bead process. For joining higher diameter pipes in steam boiler industry, combination of welding processes TIG + SMAW (Shielding Metal Arc Welding) or TIG + SMAW + SAW (Submerged Arc Welding) is usually used, depending on available equipment. Manual TIG welding process is used for root passes which are the most important and the most complex from the standpoint of weld ability (welding in non-accessible areas, denivelation in that joint area is the most evident, gap in weld joint root must be in rigid tolerance, preheating and gas shielding from root joint pipe side aggravate welding). STT welding process is process which will replace manual TIG welding process in described situation.

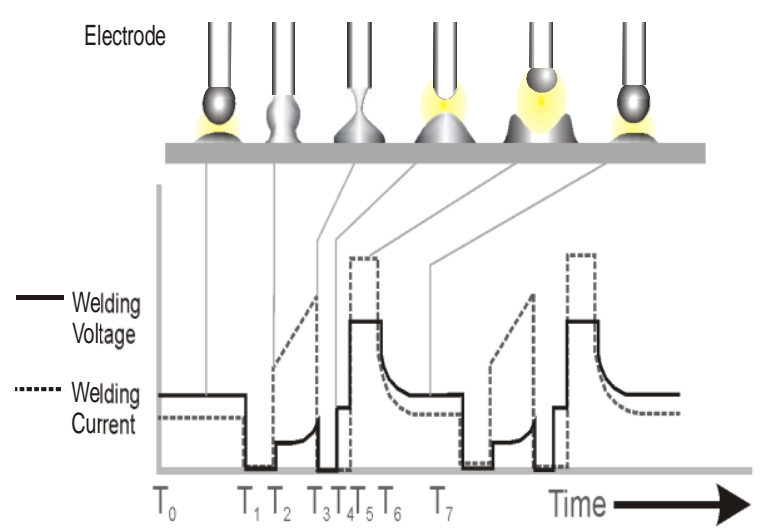

Fig. 3 Distribution of welding parameters in STT welding process

STT welding process has some differences regarding to other fusion arc welding processes: performing of welding process is in cycles, valid welding parameters set up on power source display assure stability of electric arc and the whole welding process as a repeatability of welding process and welding current is changing in milliseconds, depending of process arc voltage sensing. Distribution of welding current and voltage in electric arc during the STT welding process is shown in fig. 3 .

Main advantages of STT welding process application are:

- high welding speed and higher productivity in relationship to other fusion welding processes,

- $\quad$ especially regarding to TIG welding process,

- lower heat input $\left(\mathrm{J} / \mathrm{mm}^{2}\right)$ in relationship to TIG welding process,

- possibility of dissimilar materials joining,

- decreasing of cold taps possibilities,

- lower number of weld stops and due to this lower possibilities of failures,

- $\quad$ satisfactory welding pool control during the welding,

- lower spattering and shorter cleaning of welding joint,

- possibility of different shielding gases and gases mixture application $\left(\mathrm{CO}_{2}, \mathrm{Ar}-82 \%+\mathrm{CO}_{2}-18 \%\right.$, Ar$98 \%+\mathrm{CO}_{2}-2 \%$ )

- $\quad$ satisfactory corrosion resistance

- lower heat and light emission,

- Acceptable welding conditions for welders, etc.

\section{DESIGN METHODOLOGY \\ AND}

\section{EXPERIMENT}

The advantage of using full Gas Metal Arc Welding (GMAW) process in producing comparatively faster, long, clean, continuous weld of $20 \mathrm{~mm}$ thick wall alloy steel pipe with respect to conventionally used Shielded Metal Arc 
Welding (SMAW) process has been established. However, the necessity of applying the conventional GMAW process in short and spray modes of metal transfer in welding of root and filler passes respectively has led to high spatter, burn through and large amount of metal deposition. Control of the adverse influence of conventional GMAW on required weld joint quality has been successfully addressed by application of surface tension transfer (STT) for root pass followed by pulsed current GMAW (P-GMAW) process for filler passes.

In order to increase the productivity with desired weld joint quality, the semi- automatic welding positioner is used. Prior to its application the suitability and effectiveness of the positioner with respect to speed control and GMAW torch head manipulation in groove was tested. After that, by using the positioner, full GMAW technology for hand-hole pipe butt welding were established. The quality of weld joints has been checked and analyzed by $100 \%$ X-ray radiography. Further, to qualify the joint, conventional mechanical and metallurgical properties have been studied. Based on the results, the welding protocol was checked with reference to ASME section IX.

Total number of weld pass (including root pass) and time required for preparation of one weld joint is 10 and 30 minutes respectively. The details are given in Table 1 . Thus comparatively the new STT welding cum GMAW process is 10 times faster than the conventional GTAW cum SAW process

Table 1: Time consumption data of welding process

\begin{tabular}{|l|l|l|}
\hline Activity & $\begin{array}{l}\text { Time } \\
(\mathbf{m i n s})\end{array}$ & Process \\
\hline Tack welding & 5 & STT \\
\hline $\begin{array}{l}\text { Fixing of pipe to the } \\
\text { positioner }\end{array}$ & 1 & Manual \\
\hline Preheating for filler & 4 & \\
\hline Torch setting for root pass & 2 & Manual \\
\hline Root pass setting & Manual \\
\hline $\begin{array}{l}\text { Torch passes } \\
\text { Fill passes }\end{array}$ & $\begin{array}{l}\text { One pass } \\
=1, \\
\text { passes }=9\end{array}$ & P-GMAW \\
\hline Total dwell time & 8 & \\
\hline Dismantle & 1 & Manual \\
\hline Total Time & $37 \approx 40$ & \\
\hline
\end{tabular}

\subsection{Experimental Set Up}

\subsubsection{Design of Welding Positioner}

Suitable welding positioner along with torch head attachment used for the welding process is shown in Fig. 4. The major components of the positioner are electrical motor assembly, speed controller box with digital display, three jaw chuck and torch holding device (Fig. 4). The positioner can able to operate various welding speed by controlling the knob fitted with in speed controller box. The relationship between knob setting and corresponding rotational speed in case of handhole pipe is given in Table 2 .

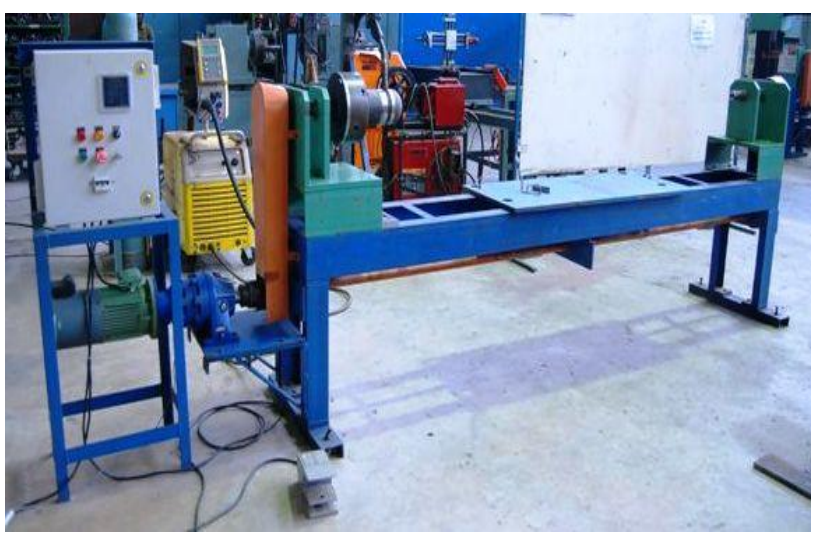

Fig.4 Photographs of welding positioner.

Table 2: Relationship between Knob Setting Vs Rotational Speed

\begin{tabular}{|l|l|l|}
\hline S. No & $\begin{array}{l}\text { Knob Setting } \\
\text { in Speed Controller } \\
\text { Box }\end{array}$ & $\begin{array}{l}\text { Corresponding } \\
\text { Rotational Speed } \\
(\mathrm{cm} / \mathrm{min})\end{array}$ \\
\hline 1 & 3 & 11 \\
\hline 2 & 4 & 14.5 \\
\hline 3 & 4.8 & 16 \\
\hline 4 & 5 & 18 \\
\hline 5 & 5.4 & 20 \\
\hline 6 & 6 & 25 \\
\hline 7 & 7 & 26 \\
\hline 8 & 7.5 & 28 \\
\hline 9 & 8.0 & 30 \\
\hline 10 & 10 & 38 \\
\hline 11 & 10.5 & 40 \\
\hline 12 & 12 & 45 \\
\hline 13 & 12.5 & 48 \\
\hline 14 & 13 & 50 \\
\hline 15 & 14 & 60 \\
\hline
\end{tabular}

\subsection{Welding}

\subsubsection{Preparation of Weld Groove}

The conventional groove design for edge preparation of the hand hole pipe and dish end were prepared by suitable machines as shown in the pattern below (fig. 5). Prior to welding, the groove surface was checked visually followed by acetone cleaning to ensure the clean groove wall.

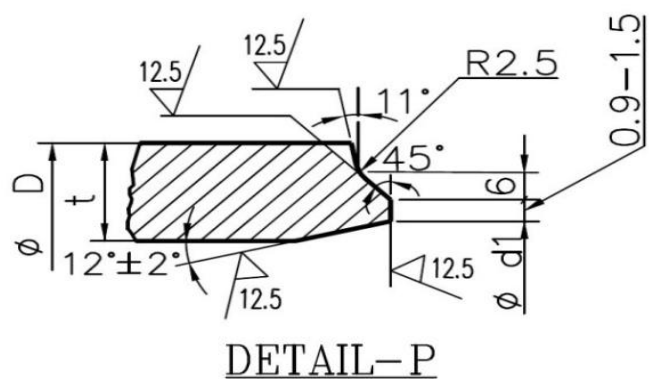

Fig. 5 Schematic diagram of chamfering groove 
The welding was carried out by multi-pass GMA welding process. During welding the pipes were held horizontally with the help of three jaws clamping system in a rotating table and the welding was carried out in 1GR position as shown in Fig. 6(a). The photographic view of the experimental setup is shown in Fig. 6(b). The root pass was carried out by wave form controlled GMAW, commonly referred as surface tension transfer (STT) process followed by pulsed current GMAW process. After each weld pass visual testing checked the appearance of the weld deposit. During welding all the parameters were recorded with the help of digital controlled meter fitted with the welding power source.

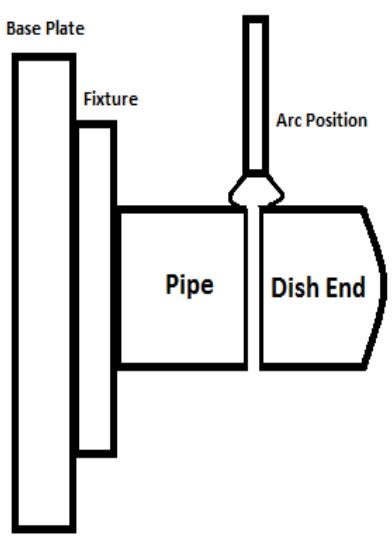

(a)

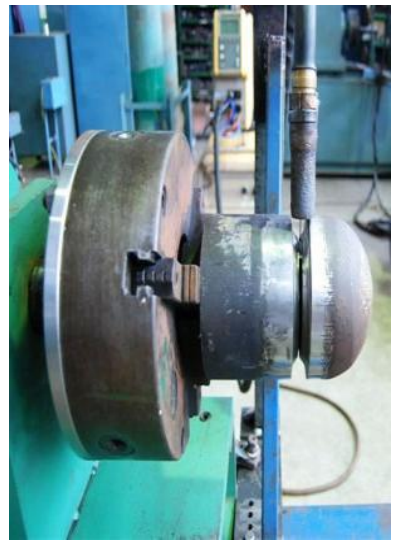

(b)
Fig. 6 (a) Schematic diagram showing the experimental set up for GMA torch nozzle location with suitable fixture for holding the pipes and (b) Photographic view of experimental setup.

\section{DESIGN OF EXPERIMENT}

For selecting the optimum parameter for welding of hand hole pipe, Taguchi's orthogonal array has been selected with 4 factors and 3 levels. The 4 factors are namely, Wire feed rate or current, Voltage, travel speed and stick out. Then 3 levels of parameters were selected. The design produced 9 runs and all the 9 runs were repeated thrice to get identical value. From output, properties like bead width, bead height and penetration was calculated. Based on the necessary penetration, bead width and bead height the parameters were selected. The L9 orthogonal array is shown in Table. 3

Table 3: Taguchi's orthogonal array method

\begin{tabular}{|l|l|l|l|}
\hline $\begin{array}{l}\text { Wire feed } \\
\text { rate/ Current, } \\
\mathrm{A}\end{array}$ & $\begin{array}{l}\text { Voltage, } \\
\text { V }\end{array}$ & $\begin{array}{l}\text { Travel speed, } \\
\mathrm{cm} / \mathrm{min}\end{array}$ & $\begin{array}{l}\text { Stick } \\
\text { out, mm }\end{array}$ \\
\hline 180 & 32 & 28 & 18 \\
\hline 180 & 34 & 30 & 17 \\
\hline 180 & 36 & 32 & 16 \\
\hline 200 & 32 & 30 & 16 \\
\hline 200 & 34 & 32 & 18 \\
\hline 200 & 36 & 28 & 17 \\
\hline
\end{tabular}

\begin{tabular}{|l|l|l|l|}
\hline 220 & 32 & 32 & 17 \\
\hline 220 & 34 & 28 & 16 \\
\hline 220 & 36 & 30 & 18 \\
\hline
\end{tabular}

The optimum parameters were around Current $215 \mathrm{~A}$, Voltage $38 \mathrm{~V}$, Travel speed $28 \mathrm{~cm} / \mathrm{min}$ and Stick out was 16 mm.

\section{RESULTS AND DISCUSSIONS}

\subsection{Testing of Welding}

\subsubsection{X-Ray Radiography}

The specifications for X-ray radiography were prepared as per ASME section V. The weld joints were fully (100\%) tested by X-ray radiography. The total circular path of the weld was divided in two or three sectors of film placement for X-ray radiography as shown schematically in Fig. 7. The shooting and marking procedures of the $\mathrm{X}$-ray radiography have been shown in Fig. 8. The weld defects revealed in the $\mathrm{X}$-ray film were analyzed and correspondingly marked in proper location of the pipe welds. The location of defects was marked in reference to the starting sector of the path. The defect analysis of the pipe welds, revealed in X-ray radiograph, has been recorded. The radiographs depicts that the defects primarily exist in the welds as lack of fusion, incomplete penetration and porosity.

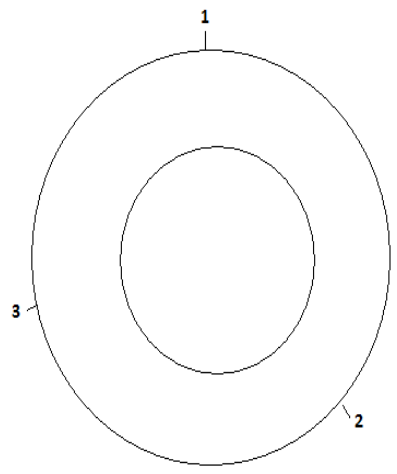

Fig. 7: Schematic diagram of film placement for X-ray radiography on total circular path of the weld divided in three sectors

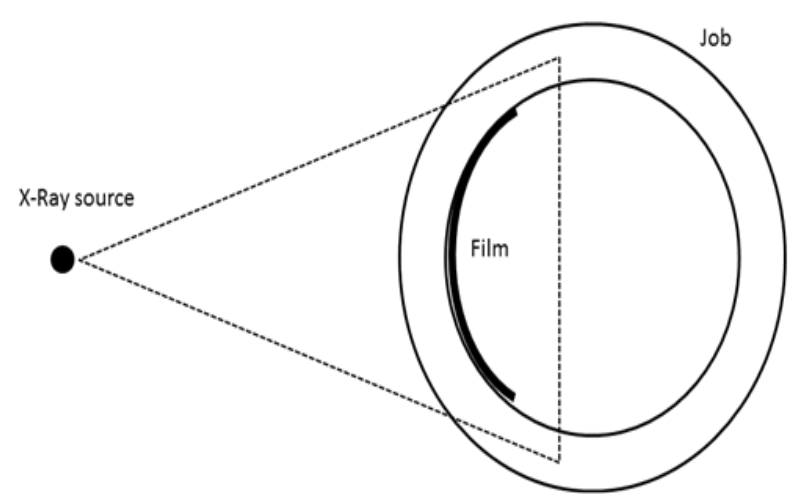

Fig. 8: Schematic diagram of shooting and marking procedures followed in the X-ray radiography of the weld joints 
Sectioning of the weld joints was made by power saw to remove the defective parts as identified by X-ray radiography. The pieces were further suitably sectioned for fabrication of various test specimens. The collection of differently oriented specimens for mechanical and metallographic testing from different location of the weld in reference to the weld joint has been schematically shown in Fig. 9.

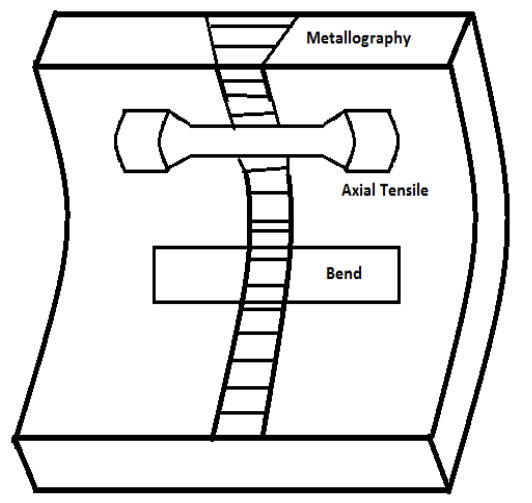

Fig.9 Schematic representation of differently oriented specimens

\subsubsection{Metallurgical Characteristics of Pipe Weld}

\section{Joint}

The metallurgical characteristics of pipe weld joint have been studied under optical microscope with respect to the microstructure of weld and heat affected zone (HAZ), as revealed in its metallographic polished and etched (alcoholic solution of $2 \% \mathrm{HNO}_{3}$ ) transverse section.

\subsection{Mechanical Testing}

\subsubsection{Tensile Test}

Tensile testing of the axial weld joint having weld at its centre has been carried out using flat tensile test specimens as per AWS B4.0 standard. The dimensions of the axial weld tensile specimen are schematically shown in Fig. 10.

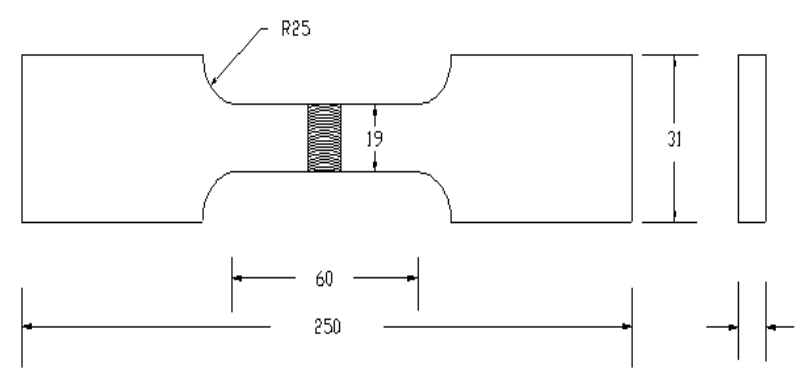

Fig. 10 Schematic diagram of tensile specimen

\subsubsection{Bend Test}

The side faces and root bend tests of pipe weld joint has been carried out as per AWS B4.0 standard. The dimensions of the bend specimen are schematically shown in Fig. 11.

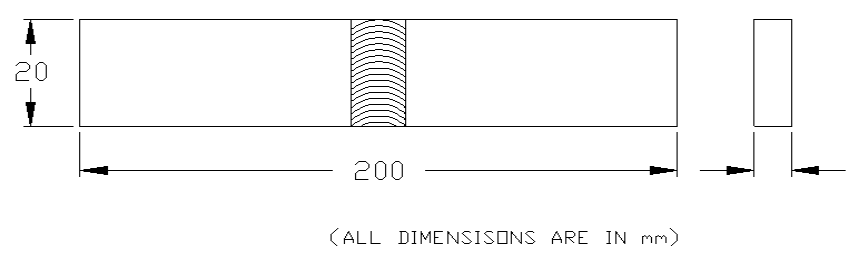

Fig. 11 Schematic diagram of bend specimen

\subsubsection{Hardness}

The distribution of hardness across the weld joint with special reference to the HAZ adjacent to fusion line was studied by Vicker's hardness testing at a load of $10 \mathrm{~kg}$. The hardness test was performed according to the ASTM E92 standard.

\section{RESULTS}

\subsection{X-Ray Radiography}

\subsubsection{Studies on Macrostructure}

The typical macrostructure of the hand-hole pipe weld joints prepared by STT root pass followed by P-GMAW process have been shown in Fig.13. The figure confirms the radiography results in reference to the soundness of weld joint.

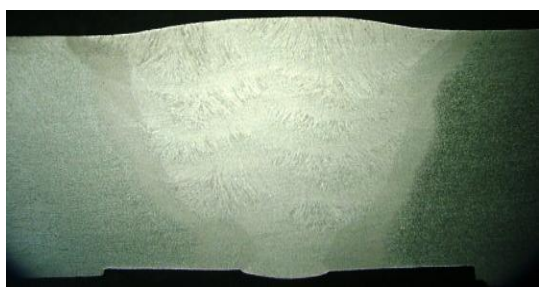

Fig. 13 Typical macro-photographs of hand-hole pipe weld joint.

\subsubsection{Studies on Mechanical Properties}

The axial tensile property of the weld joints prepared by full GMAW procedure is done. It is observed that, fracture occurred in base metal as shown clearly in the Fig. 14. The side root and face bend results of the weld joints prepared by full GMAW procedure are as also shown in Fig. 15. It is observed that, after bending the specimens are not showing any open discontinuity or cracks. Thus, it infers that the weld joints prepared by full GMAW procedure showed good formability such a behavior as shown clearly in the Fig.16.

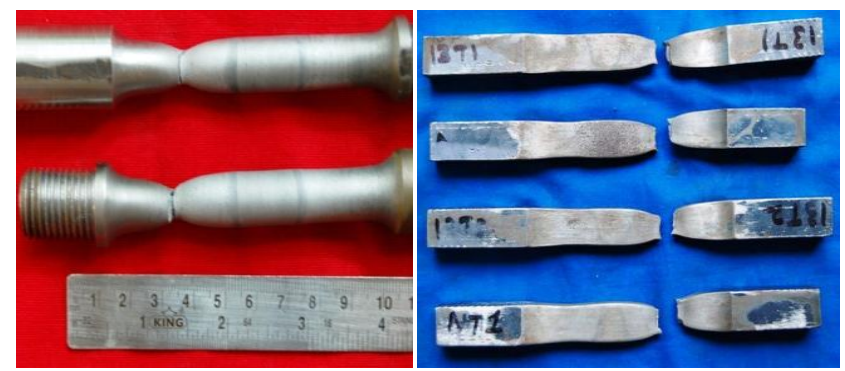

Fig.14 Photograph of fracture location of weld joints after tensile testing 


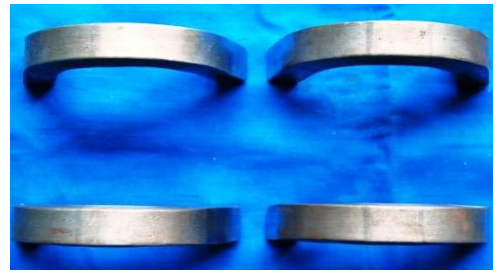

a)

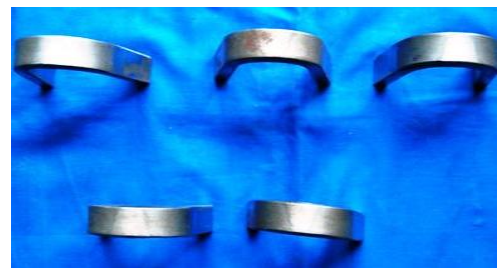

b)

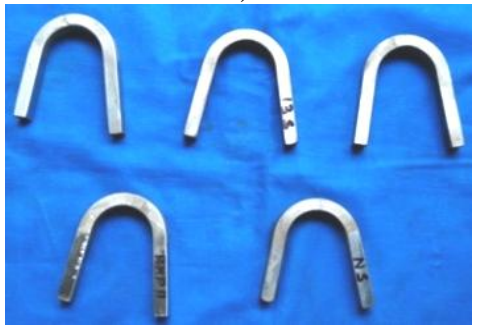

c)

Fig.15 Photograph of bend tested specimens (a) Face, (b) Root and (c) Side

$\mathrm{C}_{\mathrm{v}}$ impact toughness of the weld (as welded \& post weld heat treatment (PWHT) conditions) have been given in Table 3.

Table $3 \mathrm{C}_{\mathrm{V}}$ - Impact Toughness

\begin{tabular}{|l|l|}
\hline S.NO & $\begin{array}{l}\mathbf{C}_{\mathbf{v}} \text { Impact } \\
\text { Toughness, J } \\
\text { (After PWHT) }\end{array}$ \\
\hline 1 & 231 \\
\hline 2 & 227 \\
\hline 3 & 234 \\
\hline
\end{tabular}

Hardness of the weld joint (as welded \& post weld heat treatment (PWHT) conditions) has been given in Table 4 .

Table 4 Hardness of Weld Joint

\begin{tabular}{|l|l|l|}
\hline \multirow{2}{*}{ Location } & Hardness \\
\cline { 2 - 3 } & As welded & $\begin{array}{l}\text { After } \\
\text { PWHT }\end{array}$ \\
\hline Weld & $170 \pm 4$ & $181 \pm 2$ \\
\hline HAZ & $190 \pm 7$ & $179 \pm 2$ \\
\hline BM & $166 \pm 2$ & $155 \pm 3$ \\
\hline
\end{tabular}

The entire test reports of tensile, bend, impact and hardess have been given in below

Technique: Single wall single image (Fig. 5) to detect and evaluate internal discontinuities in butt weld.

Source of Radiation and Intensity of Radiation: X-ray of 195 $\mathrm{kV}$ and $4 \mathrm{~mA}$
Test Specification No.: ASME Section IX and ASME Section V.

Radiography Method: X-ray Source, exposure as per exposure chart to obtain optical density between 2 to 3.5 .

Extent of Examination: $100 \%$ circumference.

Maximum un-sharpness allowed: $0.5 \mathrm{~mm}$.

Focal spot to Film Distance (FFD): $750 \mathrm{~mm}$.

Film Specification: D7.

Screen Specification: Lead screen $(0.1 \mathrm{~mm}$ front and $0.15 \mathrm{~mm}$ back).

Pentameter: ASME plaque type 20.

Total Number of films: 4.

Image Quality Indicator (I.Q.I) Sensitivity: 2-2T.

Density: 2 to 3.5 .

Film Processing: Manual processing parameters.

Acceptance Standard: ASME Section IX.

The welding parameter detail of the hand-hole pipe butt weld joint prepared by STT welding process for root pass and pulsed GMAW for filler pass is shown below
Base Material \& Thickness
: SA335Gr.22\& 20mm

Dish end material

: SA234 WP.22

Filler Material\& Size

:ER90SB3\& $\phi 1.2 \mathrm{~mm}$

Groove Design

Root Gap

: P-type groove

Electrode Polarity

Welding Position

$: 2.5 \mathrm{~mm}$

: DCEP

: $1 \mathrm{GR}$

Shielding Gas \& Flow Rate

:80\%Ar+20\%CO2\&20

$1 /$ min

Preheating Temperature

Interpass Temperature

: 150 deg.C

Post Weld Heat Treatment

: 100-220 deg.C

Total Amount of Weld Metal Deposited : : $650 \pm 20$ grms

Welding parameters used for preparation of hand-hole pipe butt weld joint

Table 5 Welding Parameters

\begin{tabular}{|c|c|c|c|c|c|c|c|}
\hline \multirow{2}{*}{$\begin{array}{l}\text { Weld } \\
\text { pass }\end{array}$} & \multirow{2}{*}{$\begin{array}{l}\text { WFR, } \\
\mathrm{m} / \mathrm{min}\end{array}$} & \multirow{2}{*}{$\begin{array}{l}\text { Heat } \\
\text { Input, } \\
\mathrm{kJ} / \mathrm{cm}\end{array}$} & \multicolumn{4}{|c|}{ Welding parameters } & \multirow[b]{2}{*}{$\begin{array}{l}\text { Mode } \\
\text { of } \\
\text { Operation }\end{array}$} \\
\hline & & & $\begin{array}{l}\text { Welding/ } \\
\text { Mean } \\
\text { Current, } \\
\text { I or Im }\end{array}$ & $\begin{array}{l}\text { Arc } \\
\text { Voltage, } \\
\text { V }\end{array}$ & $\begin{array}{l}\text { Travel } \\
\text { Speed, } \\
\mathrm{S} \\
\mathrm{cm} / \mathrm{min}\end{array}$ & $\begin{array}{l}\text { Nozzle } \\
\text { to Work } \\
\text { Piece } \\
\text { Distance, } \\
\text { mm }\end{array}$ & \\
\hline 1 & 3 & 8.46 & $\begin{array}{l}\mathrm{Ip}=310 \\
\mathrm{Ib}=72 \\
\mathrm{Im}=120\end{array}$ & $18.8 \pm .1$ & 16 & 20 & $\begin{array}{l}\text { STT } \\
\text { Manual }\end{array}$ \\
\hline 2 & 8 & \multirow{2}{*}{8.17} & \multirow{9}{*}{$215 \pm 10$} & \multirow{9}{*}{$38.0 \pm 0.5$} & 60 & 18 & P- \\
\hline 3 & 8 & & & & 60 & 18 & $\mathrm{P}-$ \\
\hline 4 & 8 & \multirow{4}{*}{17.50} & & & 28 & 18 & $\mathrm{P}-$ \\
\hline 5 & 8 & & & & 28 & 17 & $\mathrm{P}-$ \\
\hline 6 & 8 & & & & 28 & 16 & $\mathrm{P}-$ \\
\hline 7 & 8 & & & & 28 & 16 & P- \\
\hline 8 & 8 & \multirow{2}{*}{16.34} & & & 30 & 15 & P- \\
\hline 9 & 8 & & & & 30 & 15 & $\mathrm{P}-$ \\
\hline 10 & 8 & 12.9 & & & 38 & 15 & $\mathrm{P}-$ \\
\hline
\end{tabular}



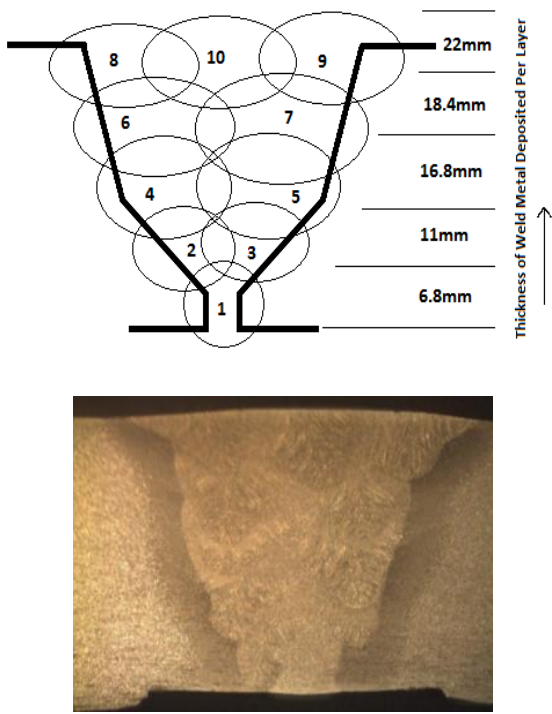

Fig.16 Cut section of layers of the welding

\section{CONCLUSIONS}

The low heat input STT root pass welding followed by the pulsed GMAW welding process is established for the hand hole pipe and dish end with the weldment of good mechanical and metallurgical properties showing fine microstructure. Thus the cycle time of the hand hole to dish end welding process is optimized by the newly designed semi-automatic welding positioner .It is concluded that by using STT + pulsed GMAW technology through the newly designed semi-automatic welding positioner, optimizes the welding cycle time and the productivity is improved ten times faster than the existing method

\section{REFERENCES}

[1] ASME, "ASME Boiler and Pressure Vessel Code, Section VIII Divi.1", 2013 Edition, the American Society of Mechanical Engineers - New York, 2013, $274-283$.

[2] Y. Kimura, T. Namekawa, and K. Ueda, Effect of Heat Input on Notch Toughness of Weld Metal. (IIW DOC. II- 418-67).

[3] K. Matsuoka, I. Takahashi, T. Yoshi, H. Iidaka, and E. Fujii, Effect of Plate Thickness and Heat Input on Fatigue Strength of Non-Load-Carrying Fillet Welded Joints. (IIW DOC. XIII-1407-91).

[4] U Kamachi Mudali, T. P. S. Gill, R. K. Dayal, and J. B.Gnanamoorthy, Effect of Heat Input on the Microstructure and Pitting Corrosion of Nitrogen added Type 304 SS Weld Metal. (IIW DOC. II-108787).

[5] L. P. Connor, ed., Welding Handbook (Eighth Edition). (Miami, FLA: American Welding Society, 1987), Vol. 1, p. 69.

[6] K. L. Kenney, K. S. Miller, and H. B. Smartt, Heat Transfer in Pulsed Gas Metal Arc Welding. (Fifth International Conference on Trends in Welding Research, J. M. Vitek et.al., eds., ASM, June, 1998, pp. 357-361).
[7] M. R. Bosworth, Effective Heat Input in Pulsed Current Gas Metal Arc Welding with Solid Wire Electrodes. Welding Journal 70(5): 111-s to117-s.

[8] E. W. Washburn et al., editors, International Critical Tables. (New York: McGraw-Hill Book Company, Inc.,1926), Vol. I, p. 102.

[9] H. B. Smartt, J. A. Stewart, and C. J. Einerson, Heat Transfer in Gas Tungsten Arc Welding. (Proc. ASM Intl. Welding Congress, ASM, 1985).

[10] D. Watkins, H. B. Smartt, and C. J. Einerson, Proc. Recent Trends in Welding and Technology, eds. S. A. David and J.M. Vitek. (ASM, 1990, pp. 19-23). 